\title{
Getting the bit below the ridge
}

\section{Leg 132 engineering and scientific parties*}

A LONG-STANDING objective of deepocean drilling has been to recover cores from the axial regions of active spreading ridges. These regions have been studied with sophisticated seismic and sonar instruments, camera sleds and manned submersibles. But until our voyage, the fresh, highly fractured character of the basalts from these regions has prevented the recovery of substantial amounts of

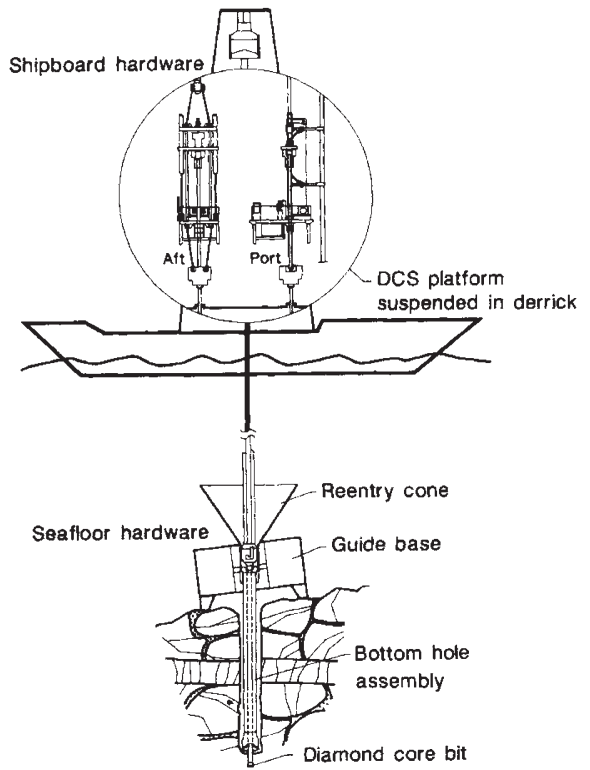

FIG. 1 Diamond coring system (DCS).

cored materials and only shallow holes have been penetrated. Now, using a specially adapted mining-type high-speed diamond coring system, we have drilled lava flows at the Sumisu Rift, an active submarine volcanic field near the Bonin island arc south of Japan.

Before this leg, ocean ridge formations were cored with conventional roller-cone bits about 10 inches in diameter, identical to bits often used in the oil industry. Recently erupted volcanic rock, however, is brittle and fractured. When rotary core bits were used in these unstable formations, the walls of the drill holes tended to collapse, binding the drill string and destroying the bit in short order. On land, such formations are drilled successfully with smaller-diameter diamond bits rotat-

* Michael A. Storms (Ocean Drilling Program, Texas A\&M Univ.). James H. Natland (Scripps Inst. of Oceanography), Univ.), James H. Natland (Scripps Inst. of Oceanography),
Garrent W. Brass (Univ. of Miami), Glenn R. Brown (Univ. of Toronto), Jean-Baptiste Fay (Institut Francais du Pétrole), Glen Foss (ODP. Texas A\&M Univ.), G. Leon Holloway (ODP, Texas A\&M Univ.), Steven P. Howard (ODP, Texas A\&M Univ.), Dietmar Krehl (Eastman Christensen GmbH, West Germany), Ralf B. Luy (Institut für Tiefbohrtechnik, West Germany), Charles N. Mckinnon, Jr. (Downey, California), Brian D. Mordaunt (DRECO Inc., Utah), Isabella Premoli-Silva (Univ. Milano), Frank Rack (ODP. Texas A\&M Univ.), Daniel H. Reudelbuber (ODP, Texas A\&M Univ.), William V. Sliter (U.S. Geological Survey), Robert J. Van Waasbergen (Scripps inst. of Oceanography) and Masatake Zaitsu (Nippon Marine Enterprises Ltd, Japan). ing at high speed with a low-level, precise drill-string weight on the bit. This action can be likened to that of a high-speed dental tool delicately cutting through the enamel of a tooth.

Such a system has now been developed for the Ocean Drilling Program for use aboard JOIDES Resolution (Fig. 1). Under the ship's 62-m derrick, a special mast $14 \mathrm{~m}$ tall supports an electric top drive used to rotate a tubing string that extends from the ship to the sea floor inside the ship's standard string of drill pipe. The diamond bit can be rotated at speeds of up to 540 revolutions per minute, 5-10 times faster than in conventional coring. Computer-controlled mechanisms keep the weight of the drill string at a uniformly low level. The paramount design objective for the diamond coring system was to adapt relatively fragile mining-drilling hardware to a configuration that could be used on a drill ship in deep water. The system needed to be strong enough to rotate a drill string reaching to the sea floor as much as $4.5 \mathrm{~km}$ beneath the ship, and delicate enough to core the fragile formations.

We tested the diamond coring system at a site (Fig. 2) located in 1,800 m of water on a small ridge of en echelon volcanic peaks in the central part of Sumisu Rift, a narrow, fault-bounded, extensional basin that has opened up during the past two million years or so to the west of the Izu-Bonin arc, south of Japan. The area has previously been surveyed extensively and sampled by submersible vessels. The ridge consists primarily of basalts with

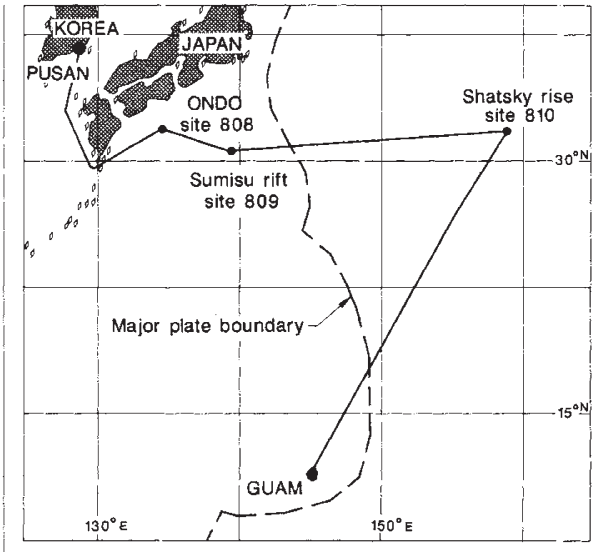

FIG. 2 Sites visited by Leg 132 .

back-arc-basin geochemical characteristics, although some more-silica-rich and hybrid lavas have been found also. There are inactive hydrothermal vents at the northern end of the cluster of volcanoes.

Coring proceeded easily through fractured basalt and unconsolidated vitroclastic breccia. In the ten days of operation we drilled a hole $79 \mathrm{~m}$ deep with more than 60 per cent of the basalts cored being recovered. In contrast, for ODP Legs 106 and 109 on the Mid-Atlantic Ridge - two previous attempts to drill young, rift-axis basalt - hole stability was a continual problem and less than a tenth of the core was recovered. The hole was abandoned after only $50.5 \mathrm{~m}$ of penetration.

Future plans for the new system, which is currently being improved, include drilling the crest of the East Pacific Rise in the eastern Pacific and high-temperature hot springs off the coast of British Columbia. The diamond coring system will eventually be used to core certain types of sedimentary formations, as well as holes 2,000-3,000 $\mathrm{m}$ deep along thickly sedimented continental margins.

\section{LOCOMOTION}

\section{The price of being a snake}

\section{Roger C. Woledge and Nancy A. Curtin}

Although most land animals use legs for moving about, it has been argued that this is inefficient compared with limbless locomotion, such as the lateral undulation of snakes, which avoids the costs at each stride of accelerating the legs and of moving the centre of gravity of the body vertically. This idea was supported by preliminary observations ${ }^{1}$ on a garter snake (Thamnophis sirtalis), which suggested that the snake's oxygen consumption was low during movement. Now, however, it has been disproved by the more detailed experiments of Walton, Jayne and Bennett, published in Science? showing that the energetic cost of locomotion of snakes is similar to that for lizards.

Walton and colleagues used black racer snakes (Coluber constrictor) weighing aboút $100 \mathrm{~g}$ and measured oxygen consumption while the snakes 'ran' on a motorized treadmill. The snakes showed two modes of locomotion. When unconfined they used lateral undulation, in which the whole body moves over the ground at the same time. In confined spaces they progressed by concertina locomotion, in which some parts of the body remain fixed while other parts move forward. Lateral undulation was studied at speeds of $0.2-0.8 \mathrm{~km} \mathrm{~h}^{-1}$. Up to 0.4 $\mathrm{km} \mathrm{h}^{-1}$ the snakes could keep moving for at least two hours, implying that they were in a steady state in which the cost of locomotion was being met by concurrent oxygen consumption. The snakes could go faster, up to $5 \mathrm{~km} \mathrm{~h}^{-1}$, but these speeds could not be maintained for so long, 